\title{
Correlation between Happy Planet Index with Education on the Example of Russia and Austria
}

\author{
Vadim Kats ${ }^{\text {a }}$, Evgeniia Marenkova ${ }^{\text {a }}$ * \\ * Corresponding author: Marenkova Evgeniia, evm18@tpu.ru \\ ${ }^{a}$ Tomsk Polytechnic University, Lenin Ave., 30, Tomsk, 634050 Russia
}

\begin{abstract}
http://dx.doi.org/10.15405/epsbs.2016.02.62

In this article we will focus on the indicators, which in our view the government should level the quality of welfare of the population. Such a future indicator is the Happy Planet Index (HPI). We have previously reviewed his history, compared the Happy Planet Index of Russia among other countries, have evaluated the factors that are expected the Index to Tomsk. We also discussed the paradox of HPI in Russia, saying that when the world crisis, the Index falls, while in Russia it grows. Now, we decided to consider the Happy Planet Index of Russia with a country that has made a breakthrough in the overall ranking. This country was Austria: in a very short period, she changed her position with 30 seats. After analyzing the policy of this country, we came to the conclusion that in this period the country much attention was given to educational programs. On that basis, we suggested the hypothesis that if the state would work to level of education in the country, then the population will be happier. To evaluate this hypothesis, we used econometric methods by building a regression model for each country. Identified factors and gave them a description.
\end{abstract}

(C) 2016 Published by Future Academy www.FutureAcademy.org.uk

Keywords: Macroeconomic indicators; happy planet index; index level of education; comparative analysis; econometric model.

\section{Introduction}

Positive dynamics of economic growth, increasing GDP, reducing unemployment and inflation are one of the main objectives of economic policy of States. Along with this, another important indicator is the provision of a decent standard and quality of life of the population. In 2006 British independent research center «New Economics Foundation» (NEF) have proposed a Happy Planet Index as an indicator showing the "real" wealth of Nations, that is, how citizens satisfied with life, how happy they are living in a country. Russia occupies one of the lowest figures: in 2006, the figure was at the level of 22.76 (172st place) in 2012 to 34.5 (122st place). For comparison, take such developed country like Austria. On the same date, the country took 61 st place (2006) and 48st (2012). In this period observed (c) (i) $\ominus$

EY NC ND This is an Open Access article distributed under the terms of the Creative Commons Attribution-Noncommercial 4.0 Unported License, permitting all non-commercial use, distribution, and reproduction in any medium, provided the original work is properly cited. 
a good breakthrough in the field of "happiness". After analyzing the economic, social and political policy of the state, we came to the conclusion that the emphasis in its development Austria made on the level of education of citizens. Education index is also one of the important indicators. Main indicators for the state are the number of people receiving higher education, members of academic exchange programs, the number of educational institutions, the number of budget places, scholarships, etc. In this regard, we can propose the following hypothesis. The state should care for its own citizens, about the level of their welfare and happiness. Following the example of the Austrian state, we can presumably live that by improving the quality of education received and the number of students and the release of greenhouse Universities respectively, we can influence the quality of life in the state in whole. That is a significant factor in determining the level of happiness of the population, there is an education, as with the best level of education, you can get a well-paid job, be able to afford a vacation, material goods, etc.

For this purpose, let econometric analysis between the level of education of inhabitants of the countries and the level of happiness of the population. The object of the research will be countries such as Russia and Austria.

The report discusses the following key points:

- $\quad$ Selection factors for building a regression model for Russia and Austria

- $\quad$ Construction of econometric models

- Identification of the most significant factors

- Conducting interdependence of the rate of people with higher education and their level of "happiness"

- Comparative characteristics of the results of the study

- $\quad$ Possible solutions and bridging gaps

We need to outline the factors for the construction of regression models. We shared next factors for Russia and Austria: the number of people receiving education; GDP per capita; the average per capita income; number examined (preventive maintenance); the number of families who received housing and improved living conditions. A resultant factor, which is influenced by all other factors, is the Happy Planet Index. These factors were selected on the basis of international index calculation: subjective life satisfaction people expect Pro-life span and so-called "ecological footprint". Since the For Russia and Austria was dis-read only 3 times, we built a model for 2006, 2009 and 2012.

\section{Regression model for Russia}

By analyzing the data of Russia, it was obtained the following equation multiple regression:

$$
\mathrm{Y}=3,306829946 * \mathrm{x} 1+5,284349539 * x 2+6,485459851 * x 3-0,037048734 * x 4-0,372836
$$
$465 * \times 5$,

where $\mathrm{x} 1$ - the number of people receiving education; $\mathrm{x} 2$ - GDP per capita; $\mathrm{x} 3$ - secondary per capita income of the population; $\mathrm{x} 4$ - number examined (preventive maintenance); $\mathrm{x} 5$ - the number of families who received housing and improved living conditions. 
http://dx.doi.org/10.15405/epsbs.2016.02.62

eISSN: 2357-1330 / Corresponding Author: Marenkova Evgeniia, Email: evm18@tpu.ru

Selection and peer-review under responsibility of the Organizing Committee of the conference

From this model, it follows that the important factors are the number of people receiving education, GRP and per capita income of the population. The number examined and the number of families who received housing are not important.

\section{Regression model for Austria}

Austria has received the following multiple regression equation in the data analysis:

$\mathrm{Y}=6,288560812 * \mathrm{x} 1+5,647489035 * \mathrm{x} 2+6,729493540 * \mathrm{x} 3-3,849473134 * \mathrm{x} 4+2,005685$ $337 * x 5$

where $\mathrm{x} 1$ - the number of people receiving education; $\mathrm{x} 2$ - GDP per capita; $\mathrm{x} 3$ - secondary per capita income of the population; $\mathrm{x} 4$ - number examined (preventive maintenance); $\mathrm{x} 5$ - the number of families who received housing and improved living conditions.

Analyzing the model for Austria, it follows that the number examined is not an important factor. All other are important.

Regarding the first indicator characterizing the level of education in this model, we can conclude that for Austria the level of education affects the Happy Planet Index, while for Russia it is a little influence. In our country, material factors are important (GRP, GDP, income level, etc.)

\section{Conclusion}

The results of the study and the regression models of such countries as Russia and Austria allow us to make the following conclusions:

Firstly, we determined that monetary factors such as GRP and income level are important and have a direct positive impact on the Happy Planet Index.

Secondly, speaking about level of education this factor is more significant for Austria than for Russia. However, it is not negative for Russia.

We also calculated the correlation index between level of education and Happy Planet Index in the studied countries. As for Russia, this indicator is equal to $0.79(<1)$, for Austria to $1.21(>1)$. It means that in Austria the relation of these figures is higher than in Russia.

\section{References}

About the Happy Planet Index. Official site of HPI. 2015. Available at: http://www.happyplanetindex.org/ (Date of access March, 25, 2015).

Rating countries on an index of happiness. Centre for Humanitarian Technologies. 2014. Available at: http://gtmarket.ru/ratings/happy-planet-index/info/ (Date of access March, 28, 2015).

The index of happiness of Russian cities. Russian Information Agency "Regions of Russia" in 2012. Available at: http://gosrf.ru/news/5927/ (Date of access March, 28, 2015).

Official statistics. Official site of the Territorial Department of the Federal State Statistics Service of the Tomsk region. 2014. Available at: http://tmsk.gks.ru/ (Date of access March, 29, 2015).

Ausan A. Institutional economics for dummies. Moscow: Fashion Press, p. 127, 2012. 